\title{
Elevated expression of orexin receptor 2 (HCRTR2) in benign prostatic hyperplasia is accompanied by lowered serum orexin A concentrations
}

\author{
WITOLD MALENDOWICZ ${ }^{1}$, MARTA SZYSZKA ${ }^{2}$, AGNIESZKA ZIOLKOWSKA ${ }^{2}$, \\ MARCIN RUCINSKI ${ }^{2}$ and ZBIGNIEW KWIAS ${ }^{1}$ \\ Departments of ${ }^{1}$ Urology and Urooncology, and ${ }^{2}$ Histology and Embryology, \\ Poznan University of Medical Sciences, Poznan, Poland
}

Received September 27, 2010; Accepted November 22, 2010

DOI: $10.3892 /$ ijmm.2010.590

\begin{abstract}
In search for the new polypeptides responsible for energy homeostasis which are also involved in regulating the growth and function of the human prostate, we assessed the expression of orexins (OXs) and of orexin receptors (OXRs) in human normal prostate and in benign prostatic hyperplasia (BPH). Conventional RT-PCR revealed the expression of OXR2 in all studied samples obtained either from normal prostates or $\mathrm{BPH}$ ones while neither preproorexin (ppOX)nor OXR1 mRNA were detected. In adenomatous prostates, expression levels of $O X R 2$ were 30 - to 40 -fold higher compared to controls. Western blot analysis demonstrated the presence of OXR2 protein in the studied samples and its expression levels were 4-fold higher in tissue samples from BPH. In normal glands, presence of OXR2-like immunoreactivity was found in the apical parts of epithelial cells as well as in smooth muscle cells of the stroma. Immunostaining for OXR2 was more intense in sections obtained from BPH. Immunohistochemistry did not detect the expression of OXR1-like protein. OXA serum concentrations were lowered in $\mathrm{BPH}$ patients (mean $\pm \mathrm{SE}$ $56 \pm 4 \mathrm{ng} / \mathrm{ml}, \mathrm{n}=12 ; \mathrm{P}<0.01)$ and unaltered in prostate cancer $(79 \pm 7 \mathrm{ng} / \mathrm{ml}, \mathrm{n}=18)$ compared to the controls $(69 \pm 2 \mathrm{ng} / \mathrm{ml}$, $\mathrm{n}=16$ ). On the contrary, serum OXB levels were similar in all studied groups of patients. We thus have demonstrated the mRNA and protein expression of OXR2, but not of ppOX and OXR1 in both normal and BPH human prostate glands. We also demonstrated notable up-regulation of OXR2 in benign
\end{abstract}

Correspondence to: Dr Witold Malendowicz, Department of Urology and Urooncology, 3 Szwajcarska St., PL-61-285 Poznan, Poland

E-mail: wmalen@amp.edu.pl

Abbreviations: OX (HCRT), orexin; ppOX (ppHCRT), preproorexin; OXA, orexin A; OXB, orexin B; OXR1 (HCRTR1), orexin receptor 1; OXR2 (HCRTR2), orexin receptor 2; BPH, benign prostatic hyperplasia; PC, prostate cancer

Key words: orexin receptor 2, benign prostatic hyperplasia, QPCR, immunohistochemistry, orexin A blood levels, human prostatic hyperplasia, an alteration accompanied by lowered serum OXA concentrations. These findings suggest that both OXA and OXR2 may be involved in the pathogenesis and/or maintenance of $\mathrm{BPH}$.

\section{Introduction}

Several lines of evidence show that some neuropeptides which control energy homeostasis, may also either directly or indirectly be involved in the development of benign prostatic hyperplasia (BPH) and prostate carcinoma (PC). In this regard, special attention is being paid on obesity and prostate cancer incidence and accumulating data suggest the higher risk of aggressive cancer development in obese patients (1-5). Leptin seems to be one of the most important factors related to obesity and $\mathrm{PC}$, and numerous rapports suggest leptin association with an increased risk of prostate cancer $(1,3,4,6-22)$. However, in human and animal prostates expression of the leptin-leptin receptor system is disputable and this system is probably not directly involved in BPH or PC development and maintenance (23-25).

Orexins [OXs; orexin-A (OXA) and orexin-B (OXB)] belong to a group of endogenous polypeptides involved in energy homeostasis. They originate from the proteolytic cleavage of preproorexin (ppOX, ppHCRT) and act through two subtypes of receptors, named OXR1 (HCRTR1) and OXR2 (HCRTR2). OXR1 almost exclusively binds OXA, whereas OXR2 is non-selective for both orexins (26-29). In search for the new polypeptides responsible for energy homeostasis which are also involved in regulating the growth and function of the human prostate, we performed studies on the expression of OXs and OXRs in human normal prostate and in BPH. To our knowledge, this is the first report demonstrating a very high expression of $O X R 2$ in BPH compared to its very low expression in normal prostate.

\section{Materials and methods}

Studies were performed on patients from the Department of Urology and Urooncology, Poznan University of Medical Sciences. The Bioethics Committee of the University provided 
Table I. Basic clinical data of patients with benign prostatic hyperplasia (BPH) and of the control group.

\begin{tabular}{lccccc}
\hline Group & $\begin{array}{c}\text { Age } \\
(\text { years })\end{array}$ & $\begin{array}{c}\text { Body weight } \\
(\mathrm{kg})\end{array}$ & $\begin{array}{c}\text { Height } \\
(\mathrm{cm})\end{array}$ & $\begin{array}{c}\text { BMI } \\
\left(\mathrm{kg} / \mathrm{m}^{2}\right)\end{array}$ & $\begin{array}{c}\text { BF } \\
(\%)\end{array}$ \\
\hline $\begin{array}{l}\text { Control } \\
(\mathrm{n}=15)\end{array}$ & $63 \pm 2$ & $84 \pm 2$ & $176 \pm 1$ & $27.0 \pm 0.7$ & $30.74 \pm 0.69$ \\
$\begin{array}{l}\text { BPH } \\
(\mathrm{n}=15)\end{array}$ & $72 \pm 2^{\mathrm{a}}$ & $86 \pm 4$ & $172 \pm 1$ & $28.9 \pm 1.2$ & $35.13 \pm 1.45^{\mathrm{b}}$ \\
\end{tabular}

Unchanged prostate glands were removed from patients who underwent total cystectomy because of bladder carcinoma (ca urotheliale, $\mathrm{n}=14$ and sarcomatoid urothelial carcinoma, $\mathrm{n}=1)$ and were subjected to molecular biology studies. BMI, body mass index $\left(\mathrm{kg} / \mathrm{m}^{2}\right) ; \mathrm{BF} \%$, body fat percentage; PSA, prostate specific antigen $(\mathrm{ng} / \mathrm{ml})$. Results are means \pm SE. The unpaired Student's t-test was used for the statistical evaluation of the differences in relation to the control group; ${ }^{\mathrm{a}} \mathrm{P}<0.01,{ }^{\mathrm{b}} \mathrm{P}<0.02$.

Table II. Conventional RT-PCR and QPCR analyses of preproorexin (ppOX), orexin receptor 1 and 2 (OXR1 and OXR2) gene expression in studied prostates.

\begin{tabular}{llclc}
\hline cDNA & $\begin{array}{c}\text { GenBank } \\
\text { Accession No. }\end{array}$ & Primer & Primer sequence (5'-3') & $\begin{array}{c}\text { Position } \\
\text { PCR product } \\
\text { size (bp) }\end{array}$ \\
\hline ppOX & NM_001524 & S & CATCTCCTTTCCCGGCTACC & $47-66$ \\
& & A & GCCCAGGAGACCTTTGTGGA & $100-119$ \\
OXR1 & NM_001525 & S & CAACAGGTTCTTGGTGAAG & $177-195$ \\
& & A & TCAGCCTCAAACTTCCTTA & $240-258$ \\
OXR2 & NM_001526 & S & CCAATAGTGCTGCGAATCC & $1379-1397$ \\
& & A & AGTTGCTGATTTGAGTGGTC & $1536-1555$ \\
HPRT & NM_000194 & S & AATCCAAAGATGGTCAAGGTC & $627-647$ \\
& & A & TTTACTGGCGATGTCAATAGG & $862-882$
\end{tabular}

HPRT (hypoxanthine-guanine phosphoribosyltransferase) is the reference gene. Oligonucleotide sequences for sense (S) and antisense (A) primers are shown.

consent for the study protocol. Before the study, every participant signed an informed consent form.

Prostates. PCR, Western blotting and immunohistochemical studies were performed on 15 normal prostates obtained from patients who underwent total cystectomy because of bladder carcinoma, and on the same number of glands obtained by adenectomy of BPH patients. Histopathologically, no significant alterations were found in normal glands, while BPH prostates had typical features of hyperplasia. Basic clinical data of studied patients are presented in Table I.

QPCR analysis. Tissue samples from normal prostates were taken from the regions adjacent to the colliculus seminalis (subsequently called the central part) and the connective tissue capsule (subsequently called the peripheral region). Tissue samples from BPH patients (adenectomy) were taken from the anterior periurethral area. Total RNA was extracted by means of the TRI reagent and the RNeasy Mini kit (Qiagen, Hilden, Germany) using the standard procedure. The concentration and purity of the RNA were determined spectrophotometrically (NanoDrop, Thermo Scientific, Waltham, USA). From every sample, $1 \mu \mathrm{g}$ of total RNA was reversely transcribed using the
MMLV reverse transcriptase kit (Novazym, Poznan, Poland) using Oligo dT (PE Biosystems, Warrington, UK) as primers. The reaction was performed at $42.8^{\circ} \mathrm{C}$ for $60 \mathrm{~min}$ (UNO II Thermocycler, Biometra, Göttingen, Germany). All primer sets were designed to span at least one intron (Table II). They were purchased from the Laboratory of DNA Sequencing and Oligonucleotide Synthesis (Institute of Biochemistry and Biophysics, Polish Academy of Sciences, Warsaw, Poland). Real-time PCR was carried out in the Roche LightCycler 2.0 (Roche) with software version 4.05. The SYBR-Green detection system was used with the above-mentioned primers. PCR reactions were carried out in $20 \mu \mathrm{l}$ mixtures, containing $4 \mu \mathrm{l}$ template cDNA, $0.5 \mu \mathrm{M}$ of each gene-specific primer and $3.5 \mathrm{mM}$ of $\mathrm{Mg}^{2+}$ ions. LightCycler FastStart DNA Master SYBR-Green I mix (Roche) was used. The real-time PCR program included a $10 \mathrm{~min}$ denaturation step to activate the Taq DNA polymerase, followed by a three-step amplification program: denaturation at $95.0^{\circ} \mathrm{C}$ for $10 \mathrm{sec}$, annealing at $58.0^{\circ} \mathrm{C}$ for $5 \mathrm{sec}$ and extension at $72.0^{\circ} \mathrm{C}$ for $5 \mathrm{sec}$. Specificity of the reaction products was routinely checked by determination of melting points $\left(0.1^{\circ} \mathrm{C} / \mathrm{sec}\right.$ transition rate $)$ and the sample was separated in a $2.5 \%$ ethidium bromide/agarose gel. All PCR reactions were performed in triplicates, and the hypoxanthine 
phosphoribosyltransferase (HPRT) gene was used as a reference to normalize the data. Templates not submitted to the RT reaction served as negative controls. PCR efficiency was assessed by a serial dilution method. Briefly, the products of the RT-PCR reactions were separated in a $2.5 \%$ agarose gel and specific bands were extracted using a DNA gel extraction kit (Millipore, Billerica, USA). The amount of extracted DNA was estimated spectrophotometrically. Extracted DNA was diluted (10-fold serial dilutions) in order to generate a standard curve for efficiency calculation. The employed version of the LightCycler software (version 4.05) allowed evaluation of the amplification efficiency plots.

Western blot analyses. Tissue samples were homogenized in RIPA buffer with the addition of protease inhibitor buffer, and were centrifuged at $600 \mathrm{x}$ g for $30 \mathrm{~min}$ at $4^{\circ} \mathrm{C}$ to remove cell debris. The protein concentration was determined by the Bradford method. For every sample, $20 \mu \mathrm{g}$ of protein were separated on a 4-20\% gradient SDS-polyacrylamide electrophoretic gel and transferred onto a nitrocellulose membrane. The transferred proteins were stained with Ponceau S. Blocking of non-specific binding and incubation with antibodies was carried out with the SNAP i.d. Protein Detection System (Millipore) according to the manufacturer's guidelines. Membranes were incubated with primary goat anti-OXR2 serum (1:100) (Santa Cruz Biotechnology). Afterwards, the membranes were thoroughly washed and incubated with a secondary horseradish peroxidase-conjugated anti-goat (Santa Cruz Biotechnology) serum. For reference purposes, GAPDH detection was performed using primary mouse monoclonal GAPDH-specific antibody (Abcam Inc., Cambridge, USA) and secondary anti-mouse antibody (Amersham). The signal was detected by the ECL Advanced Western blotting detection kit (Amersham) and visualized on the GelDoc-It ${ }^{\circledR}$ imaging system (UVP, Upland, USA) with use of the VisionWorks ${ }^{\circledR}$ LS software. Expression levels were normalized to the GAPDH densitometry values.

Immunohistochemistry (ICH). Human prostate samples were Bouin's-fixed (24 h) and paraffin-embedded. After deparaffinization and rehydration, sections were quenched by incubation in $1 \% \mathrm{H}_{2} \mathrm{O}_{2}(30 \mathrm{~min})$ and blocked with goat normal serum (30 min) (Dako X0907). Subsequently, sections were incubated with primary antibodies against ppOX, OXR1 or OXR2 (rabbit anti-preproorexin polyclonal antibody, Milipore AB3096; OXR-1 (C-19, sc-8072) and OXR-2 (C-20, sc-8074), Santa Cruz Biotechnology) for $2 \mathrm{~h}$ at room temperature or overnight at $4^{\circ} \mathrm{C}$ (dilution range 1:50-1:1000). PBS was used as the negative control. Sections were then processed with peroxidase-conjugated secondary antibodies and finally developed with DAB (Dako Real EnVision detection system, peroxidase/DAB ${ }^{+}$, rabbit/mouse, DAKO K5007). Except for pre-incubation with goat normal serum, after every step the sections were rinsed in PBS (3 times for $5 \mathrm{~min}$ ). Specimens were counterstained with hematoxylin, dehydrated, and mounted.

Serum concentrations of $O X A$ and $O X B$. Estimations were performed on serum samples obtained from patients characterized in our earlier study (30). Serum concentrations of OXA and OXB were determined in patients with $\mathrm{BPH}(\mathrm{n}=12), \mathrm{PC}$

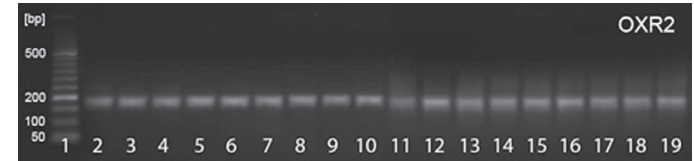

Figure 1. Ethidium bromide-stained $2 \%$ agarose gel showing prostatic cDNA amplified with human orexin receptor 2 (OXR2)-specific primers. Note the presence of the reaction products with the expected size of 177 bp. 1, DNA size marker; 2-9, control prostates (even numbers - peripheral region; odd numbers - central part); 10-19, benign prostatic hyperplasia. Negative controls (no RT of the RNA) are not shown.

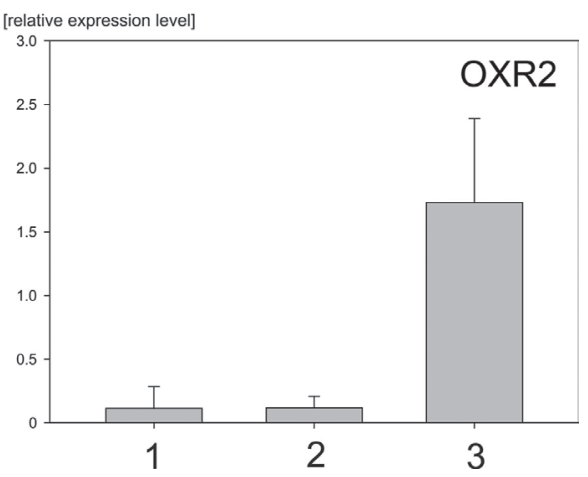

Figure 2. QPCR analyses of $O X R 2$ expression in control and BPH prostates 1 , peripheral and 2, central regions of the control; 3 , benign prostatic hyperplasia. Bars present the relative expression of the studied gene in relation to hypoxanthine-guanine phosphoribosyltransferase gene expression). Results are expressed as the means $\pm \mathrm{SE} ; \mathrm{n}>10$.

$(n=18)$ and in the control group $(n=16)$ using commercial EIA kits, following appropriate protocols (Peninsula Laboratories, OXA, cat. no. S-1374, OXB, cat. no. S-1147). Briefly, wells of the immunoplate were filled in with standard, blank (diluent only) or appropriate samples and incubated with antisera against OXA or OXB followed by addition of a biotinylated tracer. Before the next step, wells were washed 5 times, using the Labsystems Wellwash 4 and filled with a streptavidinHRP complex. Immunoplates were then washed once more (as described earlier) and TMB solution was added to each well. Finally, the reaction was terminated by $\mathrm{HCl}$ addition and within $10 \mathrm{~min}$ the absorbance was read out at $450 \mathrm{~nm}$. All steps were performed at room temperature. OXA and OXB concentrations were specified by comparing absorbance values of samples with a pre-determined standard curve.

Statistics. Data are expressed as the mean \pm SE. Statistical comparisons were done by the unpaired Student's t-test.

\section{Results}

As demonstrated in Fig. 1, conventional RT-PCR revealed the expression of $O X R 2$ in all studied samples obtained either from normal or BPH prostates. On the contrary, in all studied cases presence of neither ppOX nor OXR1 mRNA could be detected (data not shown). In all assays reaction products were of the expected length. Subsequently, we performed QPCR studies. Expression levels of $O X R 2$ were low and similar in samples taken from the central part and the peripheral region of control prostates (Fig. 2). Unexpectedly, in adenomatous 

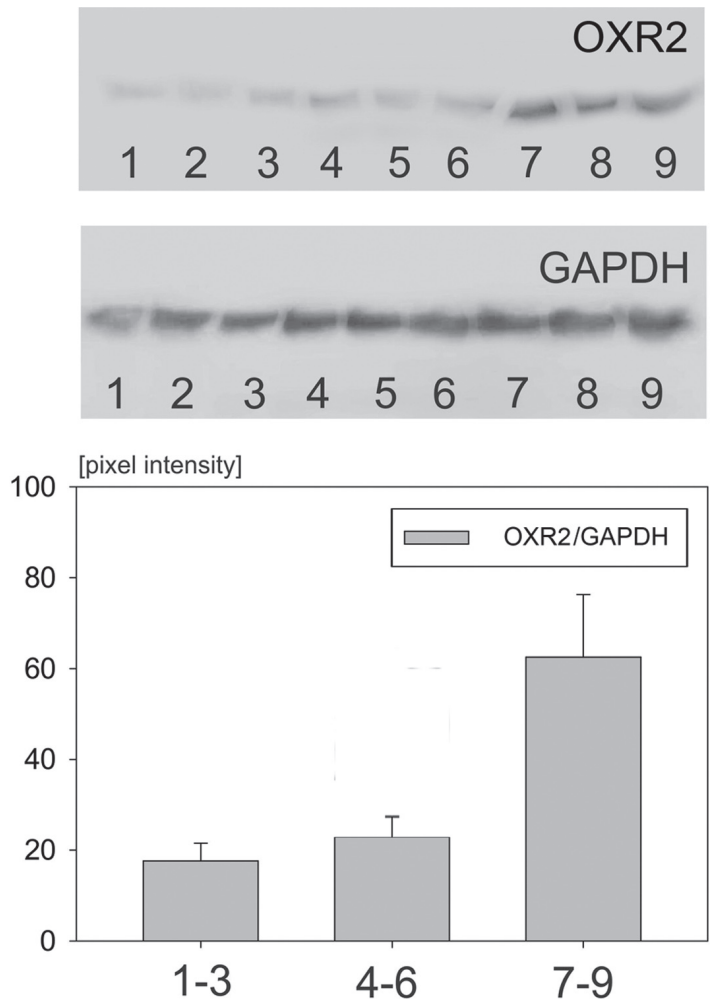

Figure 3. Semi-quantitative evaluation of OXR2 protein expression in control and $\mathrm{BPH}$ prostates. Western blotting. Upper part: chemiluminescence signals of OXR2 and GAPDH (glyceraldehyde-3-phosphate dehydrogenase) Lanes 1-3, peripheral and 4-6, central regions of the control; 7-9, benign prostatic hyperplasia. Graph: densitometric evaluation relative to GAPDH of the HCRTR2 protein expression intensity. Results are expressed as the means $\pm \mathrm{SE} ; \mathrm{n}=3$. prostates, the expression levels of the studied gene were 30- to 40 -fold higher compared to controls. Western blot analyses clearly demonstrated the presence of OXR2 protein in the studied samples (Fig. 3). In samples taken from the central part and peripheral region of control prostates the expression levels of the studied protein were similar, while in the samples from BPH they were approximately 4-fold higher.

In normal glands ICH revealed the presence of OXR2-like immunoreactivity in apical parts of epithelial cells as well as in smooth muscle cells of the stroma (Fig. 4A-C). Both in the stroma and in the epithelium numerous intensively stained cells were also present. They possessed lobated nuclei characteristic of neutrophils. Such cells seemed to migrate from the stroma, via the epithelium into the lumen of the glands. Immunostaining for OXR2 seemed to be more intense in sections obtained from BPH (Fig. 4D-F). The reaction product was visible mainly in the epithelial cells, and to a lesser degree in smooth muscle cells of the stroma. Intensively stained neutrophils were rarely seen in cases of $\mathrm{BPH}$. In all studied prostates (control and BPH ones) ICH did not reveal the expression of OXR1-like protein. There was no immunostaining in control reactions (omission of antibodies specific for OXR1 or OXR2).

Subsequently we studied OXA and OXB levels in sera of control individuals, BPH or PC patients (Fig. 5). OXA serum concentrations were lowered in $\mathrm{BPH}$ (mean $\pm \mathrm{SE}, 56 \pm 4 \mathrm{ng} / \mathrm{ml}$, $\mathrm{n}=12 ; \mathrm{P}<0.01)$ and unaltered in PC patients $(79 \pm 7 \mathrm{ng} / \mathrm{ml}, \mathrm{n}=18)$ compared to controls $(69 \pm 2 \mathrm{ng} / \mathrm{ml}, \mathrm{n}=16)$. On the contrary, serum OXB levels were similar in the control, BPH and PC patients $(36 \pm 4,38 \pm 5$ and $35 \pm 4 \mathrm{ng} / \mathrm{ml}$, respectively).
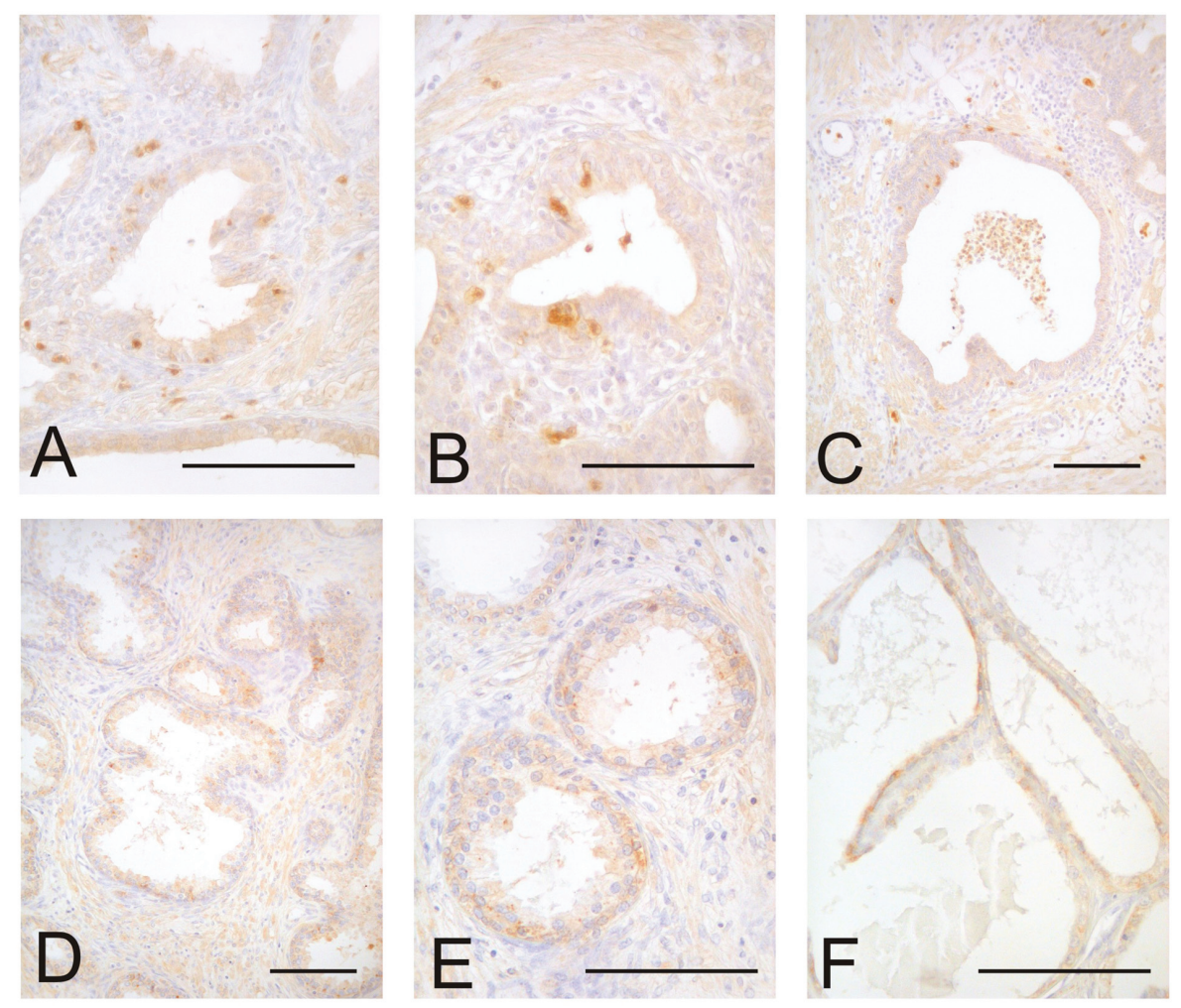

Figure 4. OXR2-like immunoreactivity in normal human prostate (A-C) and in benign prostatic hyperplasia (D-F). Immunoreactivity is seen in both epithelial cells and smooth muscle cells of the stroma. Intensely stained cells in the normal prostate possess lobated nuclei, characteristic of neutrophils. Such cells seem to migrate from the stroma (A), via the epithelium (B) into the lumen (C) of the glands. Benign prostatic hyperplasia (D-F). Note that immunostained neutrophils are not seen in BPH. Sections were counterstained with hematoxylin. Magnification is defined by bars equivalent to $100 \mu \mathrm{m}$. 


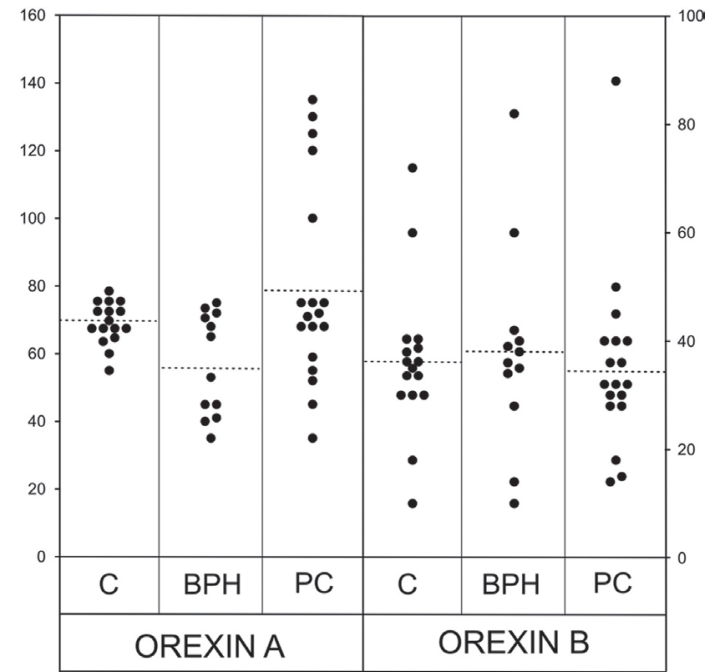

Figure 5. OXA and OXB concentrations $(\mathrm{ng} / \mathrm{ml})$ in the blood serum of the controls (C) and benign prostatic hyperplasia (BPH) and prostate cancer (PC) patients. Individual results (black dots) are presented. Broken lines correspond to the means.

\section{Discussion}

A growing body of evidence suggests that the OX-OXR system is involved in the regulation of sleep/awake conditions, reward processes as well as in feeding behavior and stress (31-35). This widely distributed system also plays an important role in regulating cell proliferation and apoptosis in both normal and cancer cells (36-44). In this regard, reports have indicated that OXs, via OXR1 or OXR2 induce apoptosis, resulting in a notable reduction in cell growth of various cancer cell lines $(37,44)$.

OXs and OXRs are also expressed in the male reproductive system (45-50). The expression pattern of this system or its elements suggests that OXs may be involved in the regulation of testosterone secretion by the Leydig cells, while their action on the remaining elements of the reproductive system may be organ-specific. In humans, RT-PCR analyses revealed that both $O X R 1$ and $O X R 2$ were expressed in the testis, epididymis, penis, and seminal vesicle, whereas $p p O X$ was expressed only in the epididymis and penis (46). By means of ICH, OXA expression could not be detected in the human prostate (51). A study on the cattle urethroprostatic complex, evaluated the expression of the orexin system in the prostate (50). By means of RT-PCR, Western blot analysis and $\mathrm{ICH}$, the expressions of ppOX in endocrine cells and of OXR1 in the exocrine cells of this complex were determined. Lack of reports on the expression of the orexin-orexin system in the human prostate prompted us to perform the present study. Our findings provide the first evidence for the expression of $O X R 2$ in the prostate and its up-regulation in BPH. Expression of both, OXR2 mRNA and protein suggested the local synthesis of OXR2 in the human prostate. On the contrary, we could not demonstrate $p p O X$ and $O X R I$ expression in either normal or adenomatous glands.

In our hands, ICH revealed the localization of OXR2-like immunoreactivity in the apical parts of the epithelial cells as well as in the smooth muscle cells of the stroma in both normal and BPH glands. In this regard it should be emphasized that in the cattle urethroprostatic complex, OXR1 was found to be expressed exclusively in the epithelial cells of the glands (50). Expression of OXRs in smooth muscle cells is well documented, especially in muscle cells of the gut. In rats, these cells mainly express OXR1, although the presence of OXR2 has also been reported, and presumably they are involved in the contractile activity of the gut (52-55). Our results suggest the expression of OXR2 in both smooth muscle and epithelial cells of the human prostate. This suggestion is supported by the presence of OXR2-like immunoreactivity in frequently migrating neutrophils of the normal prostate. As reported, these cells express OXR2 $(56,57)$. Of interest is that OXR2 immunoreactive neutrophils were only sporadically observed in BPH. In contrast with an earlier report in cattle (50), in both normal and BPH prostates we observed neither OXR1- nor OXR2-immunoreactive neuroendocrine cells and this might depend on a distinct species-dependent structure of the gland.

The novel and original findings of our study involve the demonstration of a notably enhanced OXR2 expression in hyperplastic human prostate. In both normal and BPH prostates there is a rather close interrelationship between the stroma and glandular part of the glands (58). In human BPH a 4-fold absolute increase in the expression was found in the stromal part and a nearly 2-fold increase in the glandular part (58-60). In this regard, the nearly 4-fold increase in OXR2 protein expression in $\mathrm{BPH}$ is not unexpected. However, since $O X R 2$ gene expression levels are calculated in relation to the HPRT (hypoxanthine-guanine phosphoribosyltransferase) gene, the obtained data have clearly shown a notable increase in $O X R 2$ gene expression. It may only be speculated that up-regulation of the $O X R 2$ gene in $\mathrm{BPH}$ may be connected to hyperplasia of the prostate or elimination of cells from adenomas. In this regard it is worth mentioning that in various cancer cell lines OX-stimulated apoptosis is linked to a notable reduction in cell growth $(37,44)$.

Basic clinical data indicate that BPH patients were older and had a higher percentage of body fat and serum PSA concentrations when compared with donors of the normal gland. However the range of the age and of the body fat percentage seems to indicate that these factors are not responsible for the enhanced OXR2 mRNA and protein expression in BPH.

Since in the human prostate gland ppOX is not expressed, the function of the OXR2 may be dependent on circulating OX. Therefore, we measured OXA and OXB concentrations in the serum of controls and BPH or PC patients. Surprisingly, in BPH patients serum OXA concentrations were lower than in controls, and in PC they were similar to those of controls. On the contrary, serum OXB concentrations were similar in all three studied groups. This unexpected finding may suggest that up-regulation of $O X R 2$ gene expression in the prostate of $\mathrm{BPH}$ patients may be related to the lowered levels of serum OXA. Taken together, these findings suggest that both OXA and OXR2 may be involved in BPH pathogenesis. However, the role of this system in BPH development and maintenance remains unclear and requires further investigation.

Thus, the novel data presented in this study demonstrate the mRNA and protein expression of OX2R, but not of ppOX and OXR1 in human prostate glands. Furthermore, we have 
demonstrated a notable up-regulation of OXR2 in BPH, an alteration accompanied by lowered serum OXA concentrations. These findings suggest that both OXA and OXR2 may be involved in the pathogenesis and/or maintenance of $\mathrm{BPH}$.

\section{References}

1. Freedland SJ and Aronson WJ: Examining the relationship between obesity and prostate cancer. Rev Urol 6: 73-81, 2004.

2. Freedland SJ and Aronson WJ: Obesity and prostate cancer. Urology 65: 433-439, 2005.

3. Baillargeon J, Platz EA, Rose DP, Pollock BH, Ankerst DP, Haffner S, Higgins B, Lokshin A, Troyer D, Hernandez J, Lynch S, Leach RJ and Thompson IM: Obesity, adipokines, and prostate cancer in a prospective population-based study. Cancer Epidemiol Biomarkers Prev 15: 1331-1335, 2006.

4. Buschemeyer WC III and Freedland SJ: Obesity and prostate cancer: epidemiology and clinical implications. Eur Urol 52: 331-343, 2007.

5. Mistry T, Digby JE, Desai KM and Randeva HS: Leptin and adiponectin interact in the regulation of prostate cancer cell growth via modulation of $\mathrm{p} 53$ and bcl-2 expression. BJU Int 101: $1317-1322,2008$

6. Lagiou P, Signorello LB, Trichopoulos D, Tzonou A, Trichopoulou A and Mantzoros CS: Leptin in relation to prostate cancer and benign prostatic hyperplasia. Int J Cancer 76: 25-28, 1998.

7. Chang S, Hursting SD, Contois JH, Strom SS, Yamamura Y, Babaian RJ, Troncoso P, Scardino PS, Wheeler TM, Amos CI and Spitz MR: Leptin and prostate cancer. Prostate 46: 62-67, 2001.

8. Hsing AW, Chua S Jr, Gao YT, Gentzschein E, Chang L, Deng J and Stanczyk FZ: Prostate cancer risk and serum levels of insulin and leptin: a population-based study. J Natl Cancer Inst 93: 783-789, 2001.

9. Hsing AW, Sakoda LC and Chua S Jr: Obesity, metabolic syndrome, and prostate cancer. Am J Clin Nutr 86: 843-857, 2007.

10. Stattin P, Söderberg S, Hallmans G, Bylund A, Kaaks R, Stenman UH, Bergh A and Olsson T: Leptin is associated with increased prostate cancer risk: a nested case-referent study. J Clin Endocrinol Metab 86: 1341-1345, 2001.

11. Stattin P and Kaaks R: Prostate cancer, insulin, and androgen deprivation therapy. Br J Cancer 89: 1814-1815, 2003.

12. Amling CT: Relationship between obesity and prostate cancer. Curr Opin Urol 15: 167-171, 2005.

13. Porter MP and Stanford JL: Obesity and the risk of prostate cancer. Prostate 62: 316-321, 2005.

14. Baillargeon J and Rose DP: Obesity, adipokines, and prostate cancer. Int J Oncol 28: 737-745, 2006.

15. Fowke JH, Motley SS, Cookson MS, Concepcion R, Chang SS, Wills ML and Smith JA Jr: The association between body size, prostate volume and prostate-specific antigen. Prostate Cancer Prostatic Dis 10: 137-142, 2007.

16. Fowke JH, Signorello LB, Underwood W, Ukoli FA and Blot WJ: Obesity and prostate cancer screening among African-American and Caucasian men. Prostate 66: 1371-1380, 2006

17. Gade-Andavolu R, Cone LA, Shu S, Morrow A, Kowshik B and Andavolu MV: Molecular interactions of leptin and prostate cancer. Cancer J 12: 201-206, 2006.

18. Ribeiro R, Lopes C and Medeiros R: Leptin and prostate: impli-cations for cancer prevention - overview of genetics and molecular interactions. Eur J Cancer Prev 13: 359-368, 2004.

19. Ribeiro R, Lopes C and Medeiros R: The link between obesity and prostate cancer: the leptin pathway and therapeutic perspectives. Prostate Cancer Prostatic Dis 9: 19-24, 2006.

20. O'Malley RL and Taneja SS: Obesity and prostate cancer. Can J Urol 13: 11-17, 2006.

21. Mistry T, Digby JE, Desai KM and Randeva HS: Obesity and prostate cancer: a role for adipokines. Eur Urol 52: 46-53, 2007.

22. Schenk JM, Kristal AR, Neuhouser ML, Tangen CM, White E, Lin DW and Thompson IM: Serum adiponectin, C-peptide and leptin and risk of symptomatic benign prostatic hyperplasia: results from the Prostate Cancer Prevention Trial. Prostate 69: $1303-1311,2009$

23. Malendowicz W, Rucinski M, Macchi C, Spinazzi R, Ziolkowska A, Nussdorfer GG and Kwias Z: Leptin and leptin receptors in the prostate and seminal vesicles of the adult rat. Int J Mol Med 18: 615-618, 2006
24. Malendowicz W, Rucinski M, Belloni AS, Ziolkowska A, Nussdorfer GG and Kwias Z: Real-time PCR analysis of leptin and leptin receptor expression in the rat prostate, and effects of leptin on prostatic acid phosphatase release. Int J Mol Med 18: $1097-1100,2006$

25. Malendowicz W and Kwias Z: Leptin receptor isoforms in benign prostatic hyperplasia $(\mathrm{BPH}) . \mathrm{BPH}$ and prostate cancer - no association between plasma concentrations of leptin and prostate specific antigen (PSA). Cent Eur J Urol 62: 96-100, 2009.

26. De Lecea L, Kilduff TS, Peyron C, Gao X, Foye PE, Danielson PE, Fukuhara C, Battenberg EL, Gautvik VT, Bartlett FS II, Frankel WN, van den Pol AN, Bloom FE, Gautvik KM and Sutcliffe JG: The hypocretins: hypothalamus-specific peptides with neuroexcitatory activity. Proc Natl Acad Sci USA 95: 322-327, 1998

27. Sakurai T, Amemiya A, Ishii M, Matsuzaki I, Chemelli RM, Tanaka H, Williams SC, Richardson JA, Kozlowski GP, Wilson S, Arch JR, Buckingham RE, Haynes AC, Carr SA, Annan RS, McNulty DE, Liu WS, Terrett JA, Elshourbagy NA, Bergsma DJ and Yanagisawa M: Orexins and orexin receptors: a family of hypothalamic neuropeptides and $\mathrm{G}$ protein-coupled receptors that regulate feeding behavior. Cell 92: 573-585, 1998.

28. Sakurai T: Orexins and orexin receptors: implication in feeding behavior. Regul Pept 85: 25-30, 1999.

29. Nambu T, Sakurai T, Mizukami K, Hosoya Y, Yanagisawa M and Goto K: Distribution of orexin neurons in the adult rat brain. Brain Res 827: 243-260, 1999.

30. Malendowicz W, Ziolkowska A, Szyszka M and Kwias Z: Elevated blood active ghrelin and unaltered total ghrelin and obestatin concentrations in prostate carcinoma. Urol Int 83: 471-475, 2009.

31. Willie JT, Chemelli RM, Sinton CM and Yanagisawa M: To eat or to sleep? Orexin in the regulation of feeding and wakefulness. Annu Rev Neurosc 24: 429-458, 2001.

32. Kirchgessner AL: Orexins in the brain-gut axis. Endocr Rev 23: $1-15,2002$.

33. Sakurai T: Roles of orexins and orexin receptors in central regulation of feeding behavior and energy homeostasis. CNS Neurol Disord Drug Targets 5: 313-325, 2006.

34. Spinazzi R, Andreis PG, Rossi GP and Nussdorfer GG: Orexins in the regulation of the hypothalamic-pituitary-adrenal axis. Pharmacol Rev 58: 46-57, 2006.

35. Tsujino N and Sakurai T: Orexin/hypocretin: a neuropeptide at the interface of sleep, energy homeostasis, and reward system. Pharmacol Rev 61: 162-176, 2009.

36. Malendowicz LK, Jedrzejczak N, Belloni AS, Trejter M, Hochól A and Nussdorfer GG: Effects of orexins A and B on the secretory and proliferative activity of immature and regenerating rat adrenal glands. Histol Histopathol 16: 713-717, 2001.

37. Rouet-Benzineb P, Rouyer-Fessard C, Jarry A, Avondo V, Pouzet C, Yanagisawa M, Laboisse C, Laburthe M and Voisin T: Orexins acting at native $\mathrm{OX}(1)$ receptor in colon cancer and neuroblastoma cells or at recombinant OX(1) receptor suppress cell growth by inducing apoptosis. J Biol Chem 279: 45875-45886, 2004.

38. Spinazzi R, Rucinski M, Neri G, Malendowicz LK and Nussdorfer GG: Preproorexin and orexin receptors are expressed in cortisol-secreting adrenocortical adenomas, and orexins stimulate in vitro cortisol secretion and growth of tumor cells. J Clin Endocrinol Metab 90: 3544-3549, 2005.

39. Spinazzi R, Ziolkowska A, Neri G, Nowak M, Rebuffat P, Nussdorfer GG, Andreis PG and Malendowicz LK: Orexins modulate the growth of cultured rat adrenocortical cells, acting through type 1 and type 2 receptors coupled to the MAPK p42/ p44- and p38-dependent cascades. Int J Mol Med 15: 847-852, 2005.

40. Zwirska-Korczala K, Adamczyk-Sowa M, Sowa P, Pilc K, Suchanek R, Pierzchala K, Namyslowski G, Misiolek M, Sodowski K, Kato I, Kuwahara A and Zabielski R: Role of leptin, ghrelin, angiotensin II and orexins in 3T3 L1 preadipocyte cells proliferation and oxidative metabolism. J Physiol Pharmacol 58: 53-64, 2007.

41. Heinonen MV, Purhonen AK, Mäkelä KA and Herzig KH: Functions of orexins in peripheral tissues. Acta Physiol 192: 471-485, 2008

42. Ziolkowska A, Rucinski M, Tyczewska M and Malendowicz LK: Orexin B inhibits proliferation and stimulates specialized function of cultured rat calvarial osteoblast-like cells. Int J Mol Med 22: 749-755, 2008 
43. Kagerer SM and Jöhren O: Interactions of orexins/hypocretins with adrenocortical functions. Acta Physiol (Oxf) 198: 361-371, 2010.

44. Laburthe M, Voisin T and El Firar A: Orexins/hypocretins and orexin receptors in apoptosis: a mini-review. Acta Physiol (Oxf) 198: 393-402, 2010

45. Johren O, Neidert SJ, Kummer M, Dendorfer A and Dominiak P: Prepro-orexin and orexin receptor mRNAs are differentially expressed in peripheral tissues of male and female rats. Endocrinology 142: 3324-3331, 2001.

46. Karteris E, Chen J and Randeva HS: Expression of human prepro-orexin and signaling characteristics of orexin receptors in the male reproductive system. J Clin Endocrinol Metab 89: 1957-1962, 2004.

47. Barreiro ML, Pineda R, Navarro VM, Lopez M, Suominen JS Pinilla L, Señaris R, Toppari J, Aguilar E, Diéguez C and Tena-Sempere M: Orexin 1 receptor messenger ribonucleic acid expression and stimulation of testosterone secretion by orexin-A in rat testis. Endocrinology 145: 2297-2306, 2004.

48. Barreiro ML, Pineda R, Gaytan F, Archanco M, Burrell MA, Castellano JM, Hakovirta H, Nurmio M, Pinilla L, Aguilar E, Toppari J, Dieguez C and Tena-Sempere M: Pattern of orexin expression and direct biological actions of orexin-a in rat testis. Endocrinology 146: 5164-5175, 2005.

49. Zhang S, Blache D, Vercoe PE, Adam CL, Blackerry MA, Findlay PA, Eidne KA and Martin GB: Expression of orexin receptors in the brain and peripheral tissues of the male sheep. Regul Pept 124: 81-87, 2005.

50. Russo F, Pavone LM, Tafuri S, Avallone L, Staiano N and Vittoria A: Expression of Orexin A and its Receptor 1 in the bovine urethroprostatic complex. Anat Rec 291: 169-174, 2008.

51. Nakabayashi M, Suzuki T, Takahashi K, Totsune K, Muramatsu Y, Kaneko C, Date F, Takeyama J, Darnel AD, Moriya T and Hironobu Sasano H: Orexin-A expression in human peripheral tissues. Mol Cell Endocrinol 205: 43-50, 2003.
52. Kirchgessner AL and Liu M: Orexin synthesis and response in the gut. Neuron 24: 941-951, 1999.

53. Ehrström M, Gustafsson T, Finn A, Kirchgessner A, Grybäck P, Jacobsson H, Hellström PM and Näslund E: Inhibitory effect of exogenous orexin a on gastric emptying, plasma leptin, and the distribution of orexin and orexin receptors in the gut and pancreas in man. J Clin Endocrinol Metab 90: 2370-2377, 2005.

54. Korczynski W, Ceregrzyn M, Matyjek R, Kato I, Kuwahara A, Wolinski J and Zabielski R: Central and local (enteric) action of orexins. J Physiol Pharmacol 57: 17-42, 2006.

55. Baccari MC and Calamai F: Influence of orexin A on the mechanical activity of mouse gastric strips. Regul Pept 146: 67-72, 2008

56. Steidl U, Bork S, Schaub S, Selbach O, Seres J, Aivado M, Schroeder T, Rohr UP, Fenk R, Kliszewski S, Maercker C, Neubert P, Bornstein SR, Haas HL, Kobbe G, Tenen DG, Haas R and Kronenwett R: Primary human $\mathrm{CD}^{4+}$ hematopoietic stem and progenitor cells express functionally active receptors of neuromediators. Blood 104: 81-88, 2004.

57. Vernona SD, Nicholson A, Rajeevan M, Dimulescu I, Cameron B, Whistler T and Andrew Lloyd A: Correlation of psychoneuroendocrine-immune (PNI) gene expression with symptoms of acute infectious mononucleosis. Brain Res 1068: 1-6, 2006.

58. Aumüller G: Morphologic and endocrine aspects of prostatic function. Prostate 4: 195-214, 1983.

59. Rohr HP and Bartsch G: Human benign prostatic hyperplasia: a stromal disease? New perspectives by quantitative morphology. Urology 16: 625-633, 1980.

60. Chagas MA, Babinski MA, Costa WS and Sampaio FJ: Stromal and acinar components of the transition zone in normal and hyperplastic human prostate. BJU Int 89: 699-702, 2002. 